H. Pickering recently described its properties before the Institute of Fuel, and there is little doubt that the gas, which is practically free from sulphur, will find many applications where a public gas supply is not available. The scope will be more limited under British conditions owing to the wide dispersion of gas mains and the low price of public supplies per therm. On the figures given, the price of the unit of heat in Calorgas is $29 d$. per therm. In the compressed gas trade, the cost of cylinders and distribution usually form the main item, and so it seems that the use of 'bottled gas' will depend on the extent to which those charges can be lowered by developing the market.

\section{Electrical Measurements in the Eighteenth Century}

IN the Annals of Science, 1, No. 1, January 1936, Mr. W. Cameron Walker, of Minchenden School, London, gives an interesting historical account of the detection and estimation of electric charges in the eighteenth century. Perhaps in no other branch of science could he have found a better illustration that progress in science is conditioned by the invention and improvement of instruments. Up to the time of Volta, Bennet's familiar gold leaf electroscope was the most sensitive detector of electricity. Its invention marks the end of a period of evolution beginning with the time when the experimenter obtained electrical charges by simply rubbing pieces of amber, glass or sulphur on his coat. Boyle and Newton had in turn extended the observations of Gilbert concerning the attractive powers of electrified bodies, while von Guericke came very near to anticipating Du Fay in the recognition of two opposite states of electricity. But to Hauksbee, with whom the story of the eighteenth century begins, belongs the credit of the first systematic investigation of 'electric effluvia'. He was surprised to notice that threads enclosed in an 'uncharged' globe of glass were immediately affected by the approach of a rubbed rod of sealing wax. But he makes no reference to the repulsion of the threads. For this new step we have to wait until twenty years later. In 1767, when describing a Leyden jar, Priestley writes that what electricians chiefly want to know is 'how high a phial is charged'. Methods of measuring this were soon described by Lane and Henly. Then we come to the wonderfully accurate experiments of Cavendish and the evolution of the condensing electrometer by Volta-the most skilful worker in this field. We think Mr. Walker has done well to direct attention to the valuable work done by eighteenth century electricians.

\section{Preservation of Cornish Engines}

IT is with pleasure we learn that the Cornish Engines Preservation Committee has been successful in acquiring the early winding engine at Levant Mine in Cornwall, and in leasing for a small acknowledgment rent the engine house. Levant and the adjoin. ing Botallack mine were famous for their richness in copper and tin, and for their deep workings, which extended far out under the Atlantic Ocean. The engine at Levant was designed by Francis Michell, and was probably built at the Copperhouse Foundry, Hayle, about one hundred and ten years ago. It is of the beam type with parallel motion, and has a cylinder $24 \mathrm{in}$. in diameter with a stroke of $4 \mathrm{ft}$. The total sum raised for its preservation was $£ 130$, the greater part of which, says Mr. W. T. Hooper, the honorary secretary of the fund, came from beyond the Tamar. Donations were received from the Institutions of Civil and Mechanical Engineers and the Newcomen Society, and from individuals in India, China, Australia and America. The Committee has in view the preservation of some of the larger pumping engines, and arrangements are now being made to complete the model of the $90 \mathrm{in}$. pumping engine at East Pool Mine, which was begun by the late $\mathrm{Mr}$. Oswald Swete of Truro.

\section{National Academy of the Lincei}

Ar a meeting of the National Academy of Lincei held in Rome on June 2, 1935, in the presence of H.M. the King of Italy, an account of which has just been issued by the Academy, it was announced that the new statutory regulations of the Academy, which have received the royal sanction and the approval of the head of the Government, are now being put into operation. The most notable of these regulations, because it symbolises the strict adherence of the Academy to the Fascist regime, is that the nomination of the president and vice-president (still to be announced) and of the national members is made by royal decree proposed by the Duce. The following members have been nominated under the new statutes : L. Berzolari, U. Amaldi, A. Crocco, E. Soler, A. Alessio, E. Fermi, G. Vallauri, F. Giordani, R. Fabiani, G. Quagliariello, P. Rondoni, C. Formichi, G. Bertoni, C. M. de Vecchi, L. Federzoni, G. Volpe, P. S. Leicht, A. Torre, A. Carlini, P. Carabellese, G. Della Valle, A. Solmi, S. Riccobono, S. Romano and A. de Stefani. Among the chief awards announced are the following: Prizes presented by H.M. the King : the late Prof. G. Viale, University of Genoa, for his work on physiology and pathology, and $A$. Maiuri, for his contributions to archæology ; Cannizzaro Prize in chemistry, Prof. P. Karrer, University of Zurich, for his work in biochemistry; Santoro Prize: G. Fauser, for his scientific services to the nitrogen fixation industries. In his address to the Academy on "The Tradition of Rome in the Middle Ages", Pietro Fedele concluded by emphasising the glorious role of Fascist Rome as the true successor of the Rome of the Cæsars and of the Popes.

\section{The Meaning of 'Survival'}

IN the fourth Frederic W. H. Myers Memorial Lecture, which was given by Mr. Whately Carington on October 30, 1935, and is now published by the Society for Psychical Research, the speaker stressed the importance of language in any serious considera. tion of the problem of 'personal survival' after bodily death. He pointed out that one of the great difficulties of the subject lies in the incorrect use of terms, which, although they might mean something in connexion 